\title{
Puberty Precocious Due to Chronic Lavender Oil Application
}

\begin{tabular}{|c|c|c|}
\hline Author(s) & \multicolumn{2}{|c|}{ (Delim Kurtoğlu1, \Mustafa Armut² } \\
\hline Affiliation(s) & \multicolumn{2}{|c|}{$\begin{array}{l}\text { Memorial Kayseri Hospital, Department of Pediatric Endocrinology, Kayseri, Turkey } \\
{ }^{2} \text { Memorial Kayseri Hospital, Department of Pediatrics, Kayseri, Turkey }\end{array}$} \\
\hline $\begin{array}{c}\text { Article } \\
\text { Information }\end{array}$ & $\begin{array}{l}\text { Article Type: Letter } \\
\text { Article Group: Pediatric Endocrinology }\end{array}$ & $\begin{array}{l}\text { Received: } 11.11 .2020 \\
\text { Accepted: } 14.11 .2020 \\
\text { Available Online: } 27.12 .2020\end{array}$ \\
\hline
\end{tabular}

\section{Letter to the Editor}

Dear Editor,

Puberty precocious is a problem caused by genetic mutations, organic brain problems, and environmental factors. In this article, we presented a case with puberty precocious thought to be caused or accelerated by the use of lavender for a long time.

An eight-year four-month-old girl presented with signs of acceleration in growth, pubic and axillary hair growth, and breast growth that started approximately 6 months ago. According to her medical history, she was intensely sprayed lavender to her hair every morning to prevent pediculus humanus capitis for the last year.

Physical examination revealed a height of $137 \mathrm{~cm}(92$ p, 1.40 SDS), weight $28.8 \mathrm{~kg}$ (56.p, 0.15 SDS), pubic hair Tanner stage 3, axillary hair stage 2, breast Tanner stage 3 (the diameter of breast glandular are right breast 3 , left breast $2 \mathrm{~cm}$ ). Her mid parental length is 157.5 cm SDS -0.95 SDS (maternal height is $163 \mathrm{~cm}$, father's height $165 \mathrm{~cm})$. Her bone development was accelerated and her bone age was evaluated as compatible with 11 years of age. Predictive length is calculated as $151 \mathrm{~cm}$. In pelvic ultrasonography, the uterine length was $45 \mathrm{~mm}$, endometrial line shape, ovarian volumes were $2.3 \mathrm{ml}$. In hormone analysis, $\mathrm{LH}$ and estradiol were measured as $3.69 \mathrm{IU} / \mathrm{L}$ and $97.92 \mathrm{pg} / \mathrm{ml}$ respectively. These hormonal levels are consistent with puberty. The patient situation was evaluated as accelerated puberty and leuprolide acetate was started for stopping puberty.

The emergence of secondary sex characters in girls before 8 years of age is defined as precocious puberty. ${ }^{1}$ While some genetic mutations, head trauma, tumors, arachnoid cysts, hydrocephalus and cranial radiation center can cause puberty, no specific cause can be found in most patients. Chemotherapy, Mc Cune Albright syndrome, and congenital adrenal hyperplasia may cause peripheral puberty precocious. ${ }^{1}$

Correspondence: Selim Kurtoğlu, Memorial Kayseri Hospital, Department of Pediatric Endocrinology, Kayseri, Turkey

E-mail: selimchief@gmail.com 
There is an increase in premature thelarche and puberty precocious cases all over the world. In addition to primary etiology, obesity, nutrition, dietary habits, physical activity, and endocrine disruptors may cause or accelerate pubertal progression. ${ }^{1,2}$ It has been reported that phthalates, bisphenol-A, tea tree, lavender and fennel can cause premature puberty. ${ }^{2,3}$ Endocrine disruptors may act directly, interact with genes regulating puberty, or may affect aromatize activity, sex hormone synthesis, follicle formation, breast tissue development, and estrogen signaling. ${ }^{2}$

Lavender cream is a cosmetic agent used in the form of perfumes. Lavender oil has antibacterial, antifungal, hair lice prevention, smooth muscle relaxant, sedative, and anti-depressant effects, additionally it is useful in burns and insect stings. ${ }^{4,5}$ Its hormonal effect has been determined as estrogenic and anti-androgenic. . $^{2,4}$ Lavender caused prepubertal gynecomastia as it was taken with tea tree oil, which had similar effects., ${ }^{4,5}$ Intensive use of lavender products may cause premature thelarche. ${ }^{5}$

In our case, daily lavender was used for 1 year. Thus, it can be argued that precocious puberty or accelerated puberty is associated with long-term use of lavender. This case is peculiar since precocious puberty due to the use of lavender oil has not been reported in the literature before. Also, we would like to emphasize that the exposure of lavender, tea tree (perfume, cream, shampoo, shower gel), and fennel should be questioned in girls who have premature thelarche, and puberty precocious.
Author Contributions: All of the authors declare that they have all participated in the design, execution, and analysis of the paper and that they have approved the final version.

Conflict of Interest: The authors have no conflict of interest to declare.

Financial Disclosure: The authors declared that this study has received no financial support.

Informed Consent: Written informed consent was obtained from patients who participated in this study.

Peer-review: Externally peer-reviewed.

\section{References}

1. Berberoğlu M. Precocious puberty and normal variant puberty: definition, etiology, diagnosis and current management. J Clin Res Pediatr Endocrinol 2009;1:164-174. [CrossRef]

2. Fudvoye J, Lopez-Rodriguez D, Franssen D, et al. Endocrine disrupters and possible contribution to pubertal changes. Best Pract Res Clin Endocrinol Metab. 2019;33:101300. [CrossRef]

3. Okdemir D, Hatipoglu N, Kurtoglu S, et al. Premature thelarche related to fennel tea consumption? J Pediatr Endocrinol Metab. 2014;27:175-179. [CrossRef]

4. Cavanagh HM, Wilkinson JM. Biological activities of lavender essential oil. Phytother Res. 2002;16:301-308. [CrossRef]

5. Ramsey JT, Li Y, Arao Y, et al. Lavender Products Associated With Premature Thelarche and Prepubertal Gynecomastia: Case Reports and Endocrine-Disrupting Chemical Activities. J Clin Endocrinol Metab. 2019;104:5393-5405. [CrossRef] 